Research

\title{
Scale effect on territorial disparities of sustainable human development in Morocco: a spatial analysis
}

\author{
Aomar Ibourk $^{1}$ - Soukaina Raoui ${ }^{1}$ \\ Received: 18 August 2021 / Accepted: 9 December 2021 \\ Published online: 23 December 2021 \\ (c) The Author(s) 2021 OPEN
}

\begin{abstract}
Concretizing the input of Morocco's advanced regionalization project, which aims to reduce territorial disparities for sustainable human development, is a cornerstone for achieving the Sustainable Development Goals (SDGs). Alongside the implementation of this project, we carried out a multiscale study of the scope of human development disparities in Morocco based on the new engineering of the territorial division across twelve regions, seventy-five provinces, and fifteen hundred communes. The study aimed to test the effect of scale modification to identify spatial concentrations through the communal human development index. The level of human development of a country is assessed through the convergence of its local HDI. We tested the scaling effect in 2004 and 2017 to determine the state of convergence of human development indicators. The spatial autocorrelation results showed that the distribution of capabilities at the communal scale remained concentrated in Morocco. Areas near developed communes follow the same pattern, at the expense of more distant areas. After the spatial configuration of advanced regionalization was undertaken, there was a decrease in regional and provincial disparities. This outcome is less notable at the communal level. Focusing on the microscale consequently becomes a preferable way to reduce inequalities in sustainable human development. Therefore, for the success and effectiveness of the advanced regionalization project in particular and for the achievement of the SDGs in general, spatial equity remains a necessary condition for the convergence of sustainable human development actions at the microscale.
\end{abstract}

Keywords CHDI · Spatial autocorrelation · Spatial justice · Sustainability · Targeting · Territorial human development

\section{Introduction}

The search for "sustainability" for human development is a common objective of societies. This justifies the approach of researchers to study the place occupied by different dimensions of sustainable human development in time and space. If the concept of sustainable development and the sustainable development goals (SDGs) are universal by nature, their application can only be differentiated according to the nature of the field and scale of study (national, regional, territorial). At the territorial level, geographical disparities remain a major challenge for inclusive human development in most developing countries. Indeed, human development is a multidimensional concept based on a "capability logic, " which is not limited to the economic dimension but also includes other societal health and educational aspects [1]. To promote equity in space and in time

\footnotetext{
1 The capability logic refers to the real or substantial freedom to do something.

Soukaina Raoui, Soukaina_raoui@hotmail.fr | 'LARESSGD, Faculty of Legal, Economics and Social Sciences, Cadi Ayyad University, Marrakesh, Morocco.
}

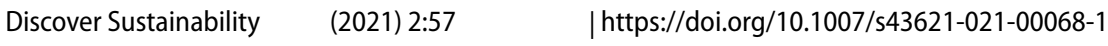


dimension, this approach of development has to address spatial and territorial issues [2]. At this juncture, spatial equity plays a crucial role at the lowest scales through the targeting and positive discrimination of small, needy communities. Addressing inequalities by moving from the macro to the micro scale in the context of interconnected geographic scales is not a simple spatial transformation but a multilevel reconfiguration process that cleverly targets political and spatial scales of action [3]. In Morocco, varied efforts to achieve the sustainable development goals (SDGs) through concerted and targeted support bring added value to national efforts for the achievement of strategic priorities, which are advanced regionalization, democratic governance, inclusion, a reduction in socioeconomic territorial and gender inequalities, and equitable education and health [4]. Indeed, since the launch of the advanced regionalization process, the issue of territorial disparities in human development has been observed to handicap the country's development process [5]. ${ }^{2}$ Despite the significant improvement in human development indicators between 1990 and 2018, Morocco's HDI rose from 0.458 to 0.676 , representing an improvement of $47.7 \%$. When comparing Morocco internationally, it ranks 121 st out of 189 countries [6]. Subrationally, disparities between regions persist; development inequality remains high and is reflected in the same regional typology that persistently favors coastal areas [7]. However, in-depth studies state that inequalities are found to be significant not only between regions but also within regions and in the most developed areas of the country, which hints of territorial problems [5]. Therefore, controlling inequalities on the microscales hidden behind national averages improves the performance of human development indicators at the national and international levels. In the Moroccan context, can the change in scale through the advanced regionalization project contribute to the convergence of human development indicators? What are the necessary conditions for the success of the advanced regionalization project in particular and for the achievement of the SDGs in general?

The upscaling and the choice of the commune as a unit of proximity and action allows better control of territorial inequalities. However, the choice of the scale of action must be accompanied by equitable planning logic. It is therefore imperative to favor a development approach based on spatial equity, which describes the prospect of revitalizing local communities and improving the living conditions of populations on a small scale, by focusing on the areas with the lowest performance in terms of human development.

Our contribution begins with an examination of the impact of the spatial reconfiguration resulting from the advanced regionalization scheme on the convergence of local human development indicators [8]. We utilized global and local spatial correlation methods to expand our analytical perspective and better understand the influence of spatial boundaries and administrative divisions (regions, provinces, and communes) on the results of statistical processing. The challenge we face is scaling our indicators to explain why inequalities do not occur in the same way at all scales. Such an assessment is particularly useful for policy in Morocco. On the one hand, it allows the monitoring and tracking of development indicators at three scales, and on the other hand, it addresses areas of deprivation in Morocco's various national socioeconomic development plans.

In this paper, after presenting the analytical framework of spatial human development in Morocco, we will highlight the perspective for considering changes in scale. This will be followed by a description of the methodology used and an examination of the data, the analysis and discussion of the results, and finally the conclusions, which will be presented in the last section.

\section{Analysis framework of territorial disparities of sustainable human development}

Addressing the issue of territorial disparities of sustainable human development implies questioning the concept of justice in its spatial and territorial dimensions. The term spatial justice emphasizes the geographical aspects of justice. This means considering everything related to the equitable and fair distribution of socially valued resources and the possibility of exploiting them [2]. It is possible to use the concept by which territorial equity aims to anticipate the repercussions of curative or corrective territorial policies at several levels, particularly in economic policy and local or regional development but also at the level of urban policy [9]. In line with Amartya Sen's concept of capabilities, this concept of territorial equity goes beyond the policy of the distribution of private goods or public spaces. Indeed, such equity requires a social environment in which individuals can truly enjoy their freedoms. At the geographical level, such an approach implies a conception of territory that is more open to the capacities of individuals to move as free beings and be conscious of their responsibilities. In this case, spaces are regarded as not only a problem but also a factor of justice.

\footnotetext{
${ }^{2}$ CCR: The consultative commission of advanced regionalization describes the main orientations of the new advanced regionalization in a report.
} 
However, sustainable human development is a concept which can essentially be summarized as equity: transgenerational equity and equity towards the most disadvantaged communities, that is, equity in terms of time and space. Even though sustainable human development calls for mobilization on a global scale, the local level is mobilized the most. Several studies have analyzed the challenges and opportunities of the SDGs at the local level and the need for political and economic upscaling through good governance by equipping local communities with the necessary funding to implement the SDGs [10-13]. In the particular case of Morocco, territorial disparities are still a handicap for achieving sustainable human development at the local and national levels. The gap between local and national scales is explained by the degree of decentralization, good governance, and coordination between local actors [14]. Subsequently, the reduction of inequalities through the promotion of spatial equity would make it possible to grasp the recent shift in Moroccan territorial policies and chart a course for sustainable human development.

The objective of linking the concept of territorial justice in Morocco to issues of territorial inequality is to show that the problem of territorial inequality in Morocco is a persistent challenge and that the marked differences between local regulatory institutions need to be highlighted [15]. Economically, the process of globalization in Morocco requires defining territories with specific management and exceptional tools (offshoring, free zones, and ad hoc territories). This process makes it possible to favor certain central territories with positive externalities in the surrounding territories. For Planel [16], this movement is, by nature, a creator of territorial inequalities. Thus, any development policy should be both subjective and corrective to prevent the creation of injustices between regions and to consider ways to reduce them.

Indeed, economic inequalities are only one component of territorial inequalities in Morocco. Inequalities in access to basic education, basic health care, housing, decent work, cultural services, etc. are also factors of dispersion. All these basic goods, as well as their possible combinations, can create a "sense of inequality" [17]. In this regard, Sen [1] offers an appropriate framework, whose exploration is able to enrich the content of development policies in Morocco. The capability approach aims to mitigate inequalities in access to real freedoms [17]. The change in scale plays an important role in favor of spatial equity of the components of the human development index. First, decentralization refers to the question of the desirable distribution of responsibilities between different levels of intervention. In health systems, the notion of a "decision space" is made up of a matrix that links the distribution of the functions to be performed with the degree of autonomy and choice that the local-level actors have over each of these functions [18]. Second, regarding job creation at the local level, reports have verified that the most resilient labor markets are locally managed [19]. Finally, it is already obvious that the administrative organization of the education system suffers from several dysfunctions. Consideration of the territory offers a favorable framework for rationally managing this sector and improving the quality of education [20]. Indeed, inequalities negatively affect the level of human development when progress in reducing deprivation does not equitably reach the entire population.

The estimation of human development indicators at the local level in Morocco is relevant in the context of the uneven regional socioeconomic development of the country and can offer a better understanding of the effectiveness of policies to promote sustainable human development [21]. There are multiple relationships between the human development index (HDI) and the 2030 Agenda. On one hand, the SDGs are a globally recognized tool for assessing development progress. On the other hand, human development is a philosophy that considers a multitude of developmental issues. In other words, the SDGs can be thought of as a development destination and human development helps design the trajectory to get there.

The HDI can be utilized as a tool to progress toward achieving the SDGs. Many of the SDGs are directly related to the $\mathrm{HDI}$, such as poverty, health, education, and employment. Others, such as peace and hunger, are indirectly related to $\mathrm{HDI}$. If the $\mathrm{HDI}$ is moving in the right direction, it is quite likely that the SDGs will also move forward. The estimation of the communal human development indicators in the Moroccan context can provide a rough indication of the progress of the country in terms of many of the SDGs.

\section{The context and analytical framework of the change in scale: international and local analysis}

\subsection{International experiences of the change in scale}

Over the past 40 years, the change in scale by decentralization and regionalization has become a major movement in the transformation of state apparatuses and public action. This is not a one-size-fits-all process. In contrast, the experiences in decentralization and regionalization are diverse. Their implementation shows that these are multidimensional policies, 
as they depend on the context of each country. From the 1970s, several European countries began decentralization and regionalization processes. Many countries changed their administrative structures. This is the case in Denmark, which in 1970 reduced the number of counties by half and the number of municipalities by six. In Portugal, the regionalization initiated in the 1990s had already been stated in the Constitution since 1976, and the autonomy of local entities (communities and regions) had been implemented since 1978. In 1993 in Belgium, the federal state replaced the decentralized unitary state in existence since 1980. In France, after the decentralization laws of 1982, the constitutionalization of the decentralized character of the Republic and the region took place in 2003. However, in developing countries (DCs), for more than 30 years, emphasis has been placed on the need to provide basic services to the population. Health, education, access to clean water, electricity, etc. are considered rights. However, most central states fail to provide access to these services; hence, the current push for a decentralized political system. A short definition of decentralization is provided by Faguet and Pöschl [22-24]: the devolution by the central (i.e., national) government of specific functions with all of the administrative, political, and economic attributes that these entail to regional and local (i.e., state/provincial and municipal) governments that are independent of the center within given geographic and functional domains. Despite historically being the most centralized states in the world, almost all states of the Middle East and North Africa region have witnessed debates on decentralization processes since the early 1990s [25]. In the wake of the so-called 'Arab Spring', decentralization reforms have gained momentum in the region [26]. For example, based on its 2014 constitution, Tunisia held its first free local elections in May 2018. As Kherigi [27]. points out, 'the Arab Spring was partially a desperate cry for help by marginalized groups and regions against highly centralized political and economic systems in which all power is concentrated in a few hands at the center.

By choosing the case of Morocco, we aim to fill a gap in the literature on decentralization in Africa that seems to consistently leave out North African countries [28], despite many similarities, not least a shared colonial history. The main features of the 'advanced regionalization' reform can be categorized into three areas: governance issues, finance and regional planning [29], which will be discussed in the following subsections.

\subsection{The Moroccan experience of the change in scale}

The issue of territorial disparities in Morocco is a problem that has lasted for over half a century and has had a negative impact on the country's development [30]. The colonial experience provides an explanation for the backlog at the subnational level. During this period (1956), the Moroccan population was very small at approximately three million, and the urbanization rate was less than 5 percent.

Colonial penetration and the expansion of the market economy to the periphery created the beginnings of territorial injustice in Moroccan geography. Indeed, the Moroccan space was divided into the first so-called useful Morocco, represented by the coastal regions, the urban axis Casablanca-Rabat-Kenitra. Following the birth of the port of Casablanca and the establishment of the national capital of Rabat, these regions became the major hub of Morocco, gathering most of the services, wealth and urban population. At the other end of the spectrum was the second, so-called useless Morocco, which was the rest of the territory, where modes of production were pre-capitalist. The state apparatus did not provide any structure for social and territorial inclusion [7]. Since 1956, citizens have faced increasing marginalization in terms of the capabilities and freedoms they had, mainly in terms of schooling.

In 1960, the illiteracy rate (of the population aged 10 years and older) was approximately $87 \%$ (i.e., nearly 9 out of 10 people were illiterate). Women were more affected than men, with a rate of $96 \%$. The region was also characterized by weak health services. The infant mortality rate was $149 \%$ in 1956 . The standard of living was alarming, with a relative poverty rate of 53\% [30]. These deficiencies were unevenly distributed throughout Morocco. A great wealth of human capacity was concentrated on the Casablanca/Rabat axis.

During this period (1960), land-use planning policy favored the most productive and immediately profitable areas, to the detriment of backward territories. The spatial disparities created by the French protectorate and the structures it put in place continued to weigh heavily on the development enterprise that Morocco did not succeed in carrying out at independence [31]. The administrative organization in Morocco first changed in 1971 from 7 regions and then, in 1997, to 16 regions. Currently, following another change in spatial scale, the country is divided into 12 regions composed of 75 provinces, which in turn are composed of 1500 urban and rural communes.

In 1983, the implementation of structural adjustment plans significantly reduced the state's efforts in the area of human development with a remarkable disengagement from the social services offered to citizens. The widening gap in Moroccan society led to an increase in inequality. Since 2000, Morocco has been committed to the Millennium Development 
Fig. 1 Evolution of human development indicators (Source: author's, DB from $[30,35])$

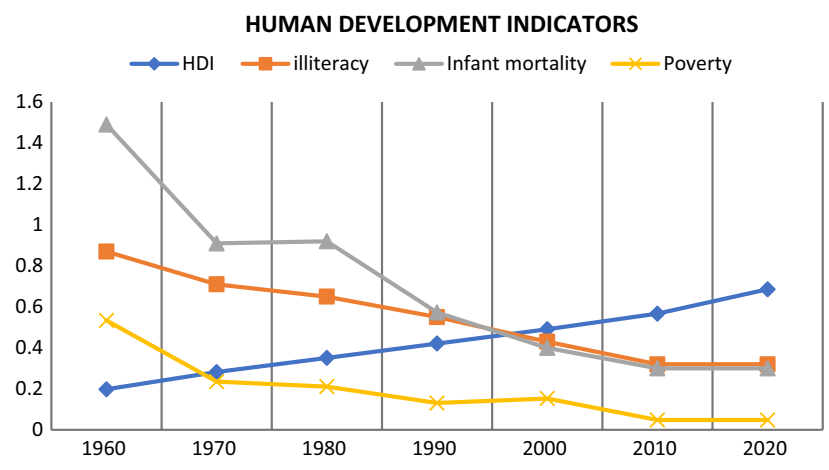

Goals (MDGs). There are eight goals, and their objective is to promote human rights and fight poverty. During the same period, Morocco experienced the proclamation of spatial planning as public policy and a national debate on spatial planning between 1999 and 2001 was organized. The question posed in the National Spatial Planning Scheme report was "what kind of territory will we leave to our children?" [32]. Morocco has changed its development model from one that was based on "planning without development" to one based on the concept of land use planning, with a view of sustainable human development through territorial rebalancing and promotion of the development of attractiveness, accessibility, and connectivity of the territories, both internally and externally [7]. However, interventions in favor of spatial organization through "top-down" spatial planning policies did not succeed in establishing a certain spatial balance. The administrative division, which is intended to be more specific to the geographical context of the commune and supposed to be a framework for mobilizing the population, is too broad for the achievement of such an objective. Spontaneous developments carried out by the population (roads, irrigation canals) take place within the framework of the village and not that of the commune. In addition, the tightening of the administrative system with the creation of ever smaller provinces leads to a gradual reduction in the size of the provinces below the size required for a regional economy. Conflicting spatial levels do not allow this, given the harmonization between these different divisions [33]. In 2004, the National Initiative for Human Development (NDHI) constituted a new approach to land use planning through an integrated vision of development based on the fight against poverty and exclusion, putting the Moroccan people at the center of concern. This new form of land use planning through spatial equity with optimal categorical and territorial targeting aimed to support the least equipped territories, to revalorize landlocked rural areas, to support people in precarious situations and to ensure equal opportunities in education, health and access to employment, i.e., representing a new form of reconciliation between national unity and regionalist aspirations. Indeed, the region was experiencing difficulties asserting itself as a relevant space to implement a real policy of territorial planning [34]. The regional institution, despite the powers vested in it by law, did not yet have the human and financial resources to rise to the rank of a real partner, participating in the governance and development of the territory. Thus, two projects constitute the cornerstone of the change of scale in Morocco. The first is the 2011 Constitution with the decentralization of power, i.e., the shift from a top-down to a bottom-up approach. The second is the regionalization project with the move from 16 to 12 regions. In 2015, Morocco unveiled the MDGs completion assessment, which stipulated that the majority of MDGs as well as some dimensions of human development have been achieved in Morocco (Fig. 1).

Extreme poverty and hunger have been virtually eradicated. The absolute poverty rate has been reduced by more than two-thirds nationally, from $21 \%$ in 1985 to $4.2 \%$ in 2014 . Primary education is virtually universal, with the net primary school enrollment rate for 6-11-year-olds reaching 99\% in 2014-2015. Literacy among the population aged 15-24 years reached $90 \%$ in 2014 . The literacy rate for the population aged 10 years and over reached $68 \%$ in 2014; however, this is still below the MDG target (80\% in 2015). At all levels of education, gender parity has been practically achieved due to positive discrimination, which has enabled the historical backlog in girls' schooling in rural areas to be eliminated. Infant and child mortality has decreased over the past 20 years. The maternal mortality rate reached the target by the end of 2015. The prevalence of HIV-AIDS remains relatively low and indigenous malaria has been eradicated, with relatively few imported cases. The incidence of tuberculosis was reduced to 82 new cases per 100,000 in 2014 from 113 in 1990. The population's access to drinking water and electricity has been generalized at a sustained rate, while liquid sanitation is being provided in urban areas with a rate of more than $90 \%$ in 2014 in a context where the proportion of the urban population living in slums or in summary dwellings has fallen from $9.2 \%$ in 1994 to $5.6 \%$ in 2014 . Morocco was among the top countries to reach the target of halving the proportion of people suffering from hunger in 2014. The proportion of the population unable to reach the minimum level of calorific intake, measured by the food poverty rate, was reduced 
Table 1 Process of advanced regionalization. Source: [38, p. 13]

\begin{tabular}{|c|c|c|}
\hline \multicolumn{3}{|c|}{ Local development } \\
\hline \multirow[t]{3}{*}{ Phase I } & 1971 & Creation of region without decision-making power \\
\hline & 1976 & Municipal charter, framework for local authorities \\
\hline & 1992 & Regions given local government status \\
\hline \multicolumn{3}{|c|}{ Limited regionalization } \\
\hline \multirow[t]{5}{*}{ Phase II } & 1996 & Creation of regions with limited powers \\
\hline & 2001 & Launch of programmes to promote regional development \\
\hline & 2002 & Local authorities become centers for economic growth \\
\hline & 2004 & First session of the Higher Council for Spatial Planning \\
\hline & 2006 & Specific credit line in the national budget \\
\hline \multicolumn{3}{|c|}{ Advanced regionalization } \\
\hline \multirow[t]{5}{*}{ Phase III } & 2010 & Consultative Regionalization Committee \\
\hline & 2011 & $\begin{array}{l}\text { Regionalization added to the constitution (Article 1) } \\
\text { Regional Land Use Planning Schemes added to the constitution }\end{array}$ \\
\hline & 2015 & Election of regional presidents, powers transferred and own budget allocated \\
\hline & 2015 & Establishment of the fund for regions and the fund for interregional solidarity \\
\hline & 2016 Until today & Adoption of 70 administrative legal texts to implement the reform \\
\hline
\end{tabular}

from $4.6 \%$ in 1985 to $0.1 \%$ in 2014 [36]. In 2015, Morocco embarked on a new program (2015-2030) for the implementation of the 17 SDGs. This was done in order to strengthen the results achieved in recent years, while providing a more comprehensive and integrated response to these problems in the background of the triple demographic, economic, and societal transition that constitutes the fundamental dimension of the major trends in the development process in Morocco. In this context, what role should the change of scale play through advanced regionalization?

\subsection{Advanced regionalization as a vector of sustainable human development}

Although the regionalization process is not recent in Morocco, it only began to be operationalized in 2010 with the establishment of the consultative commission for advanced regionalization. After the spatial reorganization of 2011, a process of economic decentralization followed the establishment of the specific fund for the Moroccan regions since 2015. The challenge is to synchronize decentralization, governance, and development of territories, particularly by making the local level the "basic brick" from which local authorities, states, and the continent will define their project, decide on their strategy, and draw and mobilize their resources for sustainable development at all levels. By relying on effective decentralization, the local space offers the possibility of inventing and implementing new modes of regulation and legitimate participatory management of public affairs and innovating and strengthening the improvement of the living environment and conditions of the population through inclusive and sustainable territorial development. Decentralization, governance, and territorial development should, therefore, be the tripod for a new society project with a collective vision and a shared understanding of the pertaining issues [37] (Table 1).

The advanced regionalization project considers the region an important level of democracy, with links to other democratic levels (communes, provinces). The objective of advanced regionalization is to create regional balances. The main design of the proposed division distinguishes two types of new regions with clear boundaries: the first includes specific destinations based on large poles or the two urban poles whose influence extends over areas of economic development, and the second class relates to remote regions in the Atlas Mountains, steppes, and deserts, which are cut off to various degrees and require the strong support of national solidarity. According to the report prepared by the committee [5], specific criteria were adopted to propose the new regional division. The new regions are characterized by the inclusion of a larger number of residents and cover a larger part of the territory, as well as a greater number of administrative districts (regions, prefectures and groupings). Although the proposed regional division is mainly derived from the current regional administrative network, it is subject to new criteria that adopt the bases of functionality and homogeneity, ease of communication and proximity, proportionality and balance. For example, the Greater Casablanca region has become Casablanca-Settat; it was logical to give depth to the economic capital by linking these two provinces. Casablanca cannot develop without expanding, especially for relocating industrial activities, among others. Casablanca therefore needs Settat, El Jadida, Azemmour and Sidi Bennour. Regarding the region of Rabat Sale, it must be noted that the metropolitan 
concept of the administrative capital Rabat far exceeds that of Kenitra. The new configuration seeks to integrate other less-developed provinces to prioritize an important region [5]. In general, spatial reorganization constitutes an opportunity for local actors (regional, provincial and communal) to fight against local disparities. Our objective is to analyze the impact of this project on territorial inequalities in human development and to analyze at what scale the visibility of inequalities is most effective for public decision-makers.

How then can a change in scale be interpreted in this context, and what relation is there with the territorial inequalities of human development in Morocco? As described by Bret [3], the analysis at a micro scale is like "a photograph with small details of reality that reveals realities invisible to the eye, variations in geographical scale, to not only contextualize what was already seen but also highlight new explanatory factors and new social actors" [3, p. 1]. Therefore, multiscaling is not so much a process of demonstration as a true scientific approach to understanding and interpreting the depth of knowledge of reality. In Morocco, the issue of territorial inequalities in human development must be analyzed on a micro-level. In the context of territorial equity, the regional analysis in Morocco still shows the persistence of inequalities, not only interregional but also intraregional. It is therefore important to shift the analysis of disparities to the lower level of the province and, more specifically, the commune. Therefore, microlevel analysis is an appropriate framework for action in favor of justice.

\section{Materials and methods}

\subsection{The data}

The composition and methodology of the HDI have evolved over time. At the subnational level, the regional human development index estimated for 1998 [39] and the Communal human development index "CHDI 2004" were constructed based on data from the 2004 General Census of Population and Housing [40]. In this study, we use the methodology of the High Commission for Planning [8] based on data from the General Population Census [41] regarding health status, education level, and standard of living [8].

The formulation of the HDI is based on the approach advocated by the UNDP, used in the 2015 Human Development Report. The HDI is the geometric mean of three indices regarding education, health, and living standards.

In this study, we mobilized communal human development indicators calculated by the HCP between 2004 and 2017. The HDI is a composite index with three components: health, measured by life expectancy at birth; educational attainment, measured by an indicator combining the adult literacy rate with a weight of two-thirds and the gross enrolment ratio (all levels combined) with a weight of one-third; and standard of living, measured by real GDP per capita (expressed in purchasing power parity). The communal human development index ( $\mathrm{CHDI}$ ) used here is measured by three elements comparable to those of the $\mathrm{HDI}$ and obtained from the results of the September $2004 \mathrm{RGPH}$. These are the following:

1. The health situation according to the infant mortality rate, i.e., the number of infant deaths per 1000 live births during the reference year of the 2004 and 2017 census. This rate is used by specialized agencies of the United Nations (UNICEF, UNDP and WHO) as an indicator of the state of development of countries in the area of health,

2. The level of education, measured by an indicator combining, for the literacy rate of people aged " 10 years and over" with a weight of two-thirds and the schooling rate of those aged between " 7 and 12 years" with a weight of one-third, and

3. The standard of living, approximated, in the absence of income data, by the average annual expenditure per person, an approach that is more appropriate for assessing the ability of households to cover their needs at the communal level than the unavailable indicator of per capita GDP. These three components of the HDI, combined in accordance with the methodology recommended by the World Development Report [39], summarize the HDI:

$$
H D I_{i t}=I_{\text {health }}^{\left(\frac{1}{3}\right)} * I_{\text {education }}^{\left(\frac{1}{3}\right)} * I_{\text {income }}^{\left(\frac{1}{3}\right)},
$$

where $\mathrm{i}=$ Regions, provinces, communes; $\mathrm{t}=2004,2017$ 


$$
\begin{gathered}
I_{\text {health }}=\frac{E V N-20}{83.6-20}, \\
I_{\text {income }}=\frac{\ln (R N B)-\ln (100)}{\ln (87478)-\ln (100)}, \\
I_{\text {Education }}=\frac{\text { combined education index }}{0.971}=\frac{\sqrt{\frac{\text { Mean Years of Schooling }}{13.3}}+\frac{\text { Expected Years o Schooling }}{18}}{0.971},
\end{gathered}
$$

where

$$
\begin{gathered}
\text { Combined education index }=\sqrt{(M Y S * E Y S)}, \\
I M Y S=\frac{M Y S-0}{13.3-0} I E Y S=\frac{E Y S-0}{18-0} .
\end{gathered}
$$

\subsection{Methods for exploratory analysis of spatial data}

Our study is based on a quantitative approach. We rely on exploratory spatial data analysis [42]. The choice of spatial autocorrelation allows us to identify whether the human development indicator at the local level is distributed randomly or whether it is concentrated around developed areas in Morocco. These methods consider the relative positions of the data through the inclusion of spatial weight matrices. The comparison of a spatial observation with neighbors was accounted for directly. In addition, these methods provide measures for global and local spatial autocorrelation. Spatial autocorrelation is defined as the measure of the strength of the relationship between the proximity of locations and their degree of similarity [43]. If the spatial autocorrelation is positive, neighbouring local units tend to be similar. Spatial autocorrelation is negative if nearby places tend to be different.

The Moran Index (I) is the statistic most widely used to test for the presence of global spatial autocorrelation, although it does not provide information about the potential shape of spatial autocorrelation [44-46]. The test statistic is as follows:

$$
\text { Moran's I it }=\frac{\mathrm{n}}{\sum_{\mathrm{i}} \Sigma_{\mathrm{j}} \mathrm{w}_{\mathrm{ij}}} \times \frac{\sum_{\mathrm{i}} \Sigma_{\mathrm{j}} \mathrm{w}_{\mathrm{ij}}(\mathrm{zi}-\overline{\mathrm{Z}})(\mathrm{zj}-\overline{\mathrm{Z}})}{\sum_{\mathrm{i}}(\mathrm{zi}-\overline{\mathrm{Z}})^{2}},
$$

where $\mathrm{i}=$ Regions, provinces, communes; $\mathrm{t}=2004,2017$.

zi: denotes the value of the variable under study for a scale of study (region, province, commune); i is the overall mean; $\mathrm{n}$ is the number of regions, provinces, and communes; $\mathrm{m}$ is the total number of pairs of neighbors; and wij is the intensity of the spatial interaction that exists between the two units $\mathrm{i}$ and $\mathrm{j}$.

The nature of the interactions between the spatial units is grouped into a spatial connectivity matrix, also called the "adjacency matrix" or the "weight matrix."This matrix contains as many rows and columns as there are spatial units. The elements of this matrix tell us how the two regions $i$ and $j$ are connected. Given the spatial configuration of the provinces, characterized by a high heterogeneity of their sizes [47], we chose the first-order contiguity matrix. This matrix considers that two regions are simply connected if they have common borders. In this study, we adopt the contiguity principle as a measure of the interaction between two provinces. $m=\Sigma i \Sigma$ jwij is the sum of the interaction coefficients. Moran's I statistic is a global statistic and does not assess the local regional structure of spatial autocorrelation. Its formula is as follows:

$$
\Gamma_{\mathrm{i}}=\sum_{\mathrm{j}} \mathrm{w}_{\mathrm{ij}} \mathrm{v}_{\mathrm{ij}}
$$




$$
\mathrm{v}_{\mathrm{ij}}=\frac{\left(\mathrm{z}_{\mathrm{i}}-\overline{\mathrm{Z}}\right)\left(\mathrm{z}_{\mathrm{j}}-\overline{\mathrm{Z}}\right)}{\Sigma_{\mathrm{i}}\left(\mathrm{z}_{\mathrm{i}}-\overline{\mathrm{Z}}\right)^{2}} .
$$

The global index is the sum of all local indices:

$$
\Gamma=\sum_{\mathrm{i}} \Gamma_{\mathrm{i}} \sum_{\mathrm{i}} \sum_{\mathrm{j}} \mathrm{w}_{\mathrm{ij}} \mathrm{v}_{\mathrm{ij}}
$$

The two main properties that local indices must fulfil to be considered local indicators of spatial association (LISA) as defined by Anselin [48], are as follows: (i) for each observation, they provide indications of a possible clustering of similar values (or opposite trends) in the vicinity, and (ii) the sum of the local indices over all observations is proportional to the corresponding global index.

\subsection{The scatterplot}

The Moran diagram allows us to appreciate local spatial instability [49], and highlight spatial grouping patterns. Indeed, by applying this procedure to our variable, we can define the spatial clusters in Morocco, which include regions, provinces, and communes with fairly similar characteristics.

Each territory estimates its similarity to its neighbors relative to the whole sample. This comparison can take the form of a scatterplot with the values of the variable for the territories on the $x$-axis and the average values of the variable for the neighbouring territories on the $y$-axis. This "Moran scatterplot" according to the terminology of Luc Anselin [49], which offers a quick reading of the spatial structure, is composed of four quadrants: quadrants 1 and 3 indicate positive spatial autocorrelation (neighbors are similar), and quadrants 2 and 4 indicate negative spatial autocorrelation (neighbors are dissimilar):

1. $\mathrm{HH}$ : The high-high situation occurs when the variable of interest shows a strong value in a neighborhood that is similar (positive spatial autocorrelation and high index value);

2. LH: The low-high situation occurs when the variable under study shows a low value in a neighborhood that is not similar (negative spatial autocorrelation and low index value);

3. LL: The low-low situation occurs when the studied variable shows a low value in a neighborhood that is similar (positive spatial autocorrelation and low index value);

4. HL:The high-low situation occurs when the studied variable shows a high value in a neighborhood that is not similar (negative spatial autocorrelation and high index value).

\subsection{Scale of analysis}

In geography, the scale or echelon corresponds to the set of levels that make up a region [50]. The diversity of points of view on an object of study often involves a variation in the level of analysis (set of scales). The change in scale corresponds to a change in focus rather than a change in neighborhood. The disappearance of details as one "climbs" geographical levels and its contribution to the understanding of phenomena and their structures have already been well emphasized [51].

The implication of the change in scale for spatial autocorrelation that we wish to retain, in terms of the results of the measurement (and therefore its interpretation) and its relation to a larger geographical "problem," underlines two statistical consequences for the values of the spatial data. The first is called the scale effect, and the second is the zoning effect. The scale effect emphasizes the variations in the data when changing the level of observation, especially the statistical smoothing effect that appears when aggregating the data. The zoning effect emphasizes the impact of the forms of territorial divisions on the results. The zoning effect is characteristic of administrative divisions and accompanies the scale effect [52].

The values of local human development indices calculated at a specific geographical scale depend closely on the divisions considered (regions, provinces, and communes). The modifiable areal unit problem (MAUP) [53,54], refers to the influence of the spatial division on the results of statistical processing. However, recent studies have shown that discretizing spaces can 

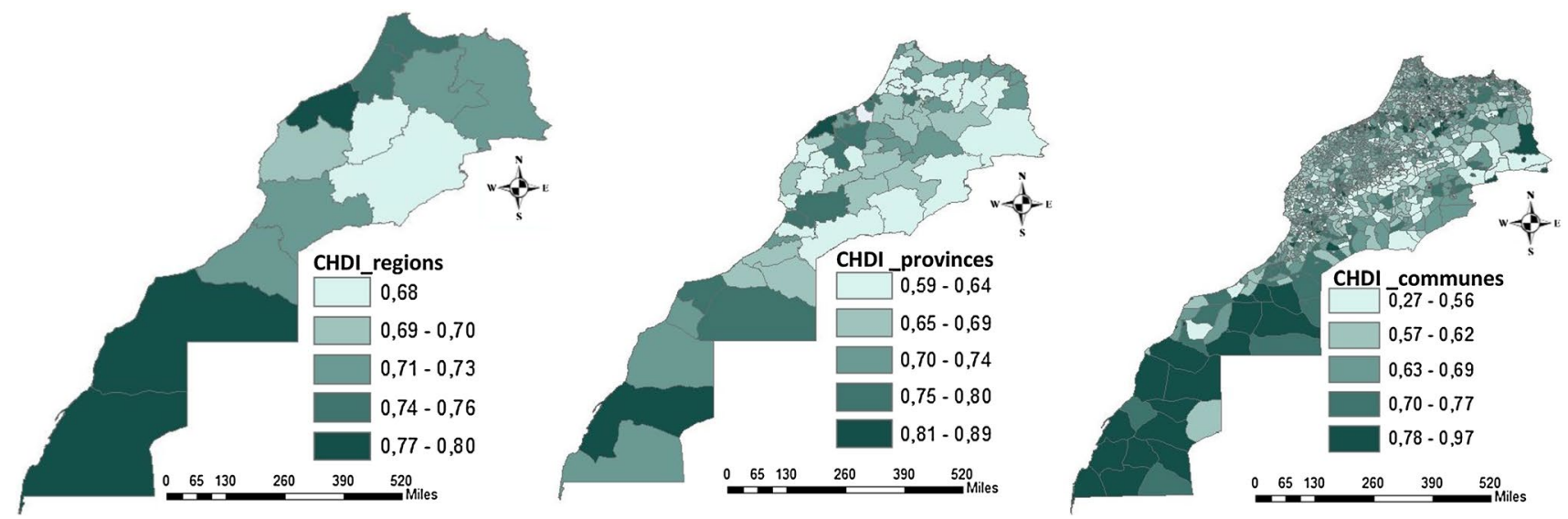

Fig. 2 Communal human development index by 12 regions, 75 provinces, 1500 communes (2017) (Source: author's, DB from [8])

generate biases [55]. More specifically, the irregular shapes and boundaries of administrative grids that do not necessarily reflect the reality of the spatial distributions studied are an obstacle to the comparability of unevenly subdivided spatial units. The concentration indices used in the literature are also measures that are dependent on the geographical scale adopted. Indeed, for the same area, concentration measured at the communal and departmental scales can lead to different conclusions, while the geographic distribution is the same, and the variation in values (and conclusions) depends solely on how the data are geographically aggregated [56]. According to Openshaw [57], the MAUP is a combination of two distinct but related problems.

The scale effect is related to a variation in information generated when a set of spatial units is aggregated to form fewer and larger units for the purposes of analysis or for data availability issues. In this case, if the areas are too few, they will be too homogeneous, while an excessively high number of areas increases the risk of not having observations on the variables of interest. However, increasing or decreasing the number of regions that divide the territory only reflects the effect of scale if the zones are part of an interlocking logic. If this is not the case, the MAUP scale effect is not relevant.

The problem of aggregation (or zoning; zone effect or shape effect) is related to a change in the diversity of information generated by the different possible aggregation schemes at the same scale. This effect is characteristic of administrative divisions and accompanies the scale effect. To emphasize the importance of this issue, we study the sensitivity of the spatial autocorrelation indices. The originality of this contribution lies in distinguishing and evaluating each of these effects by testing the indices against the scale effect.

\section{Results and discussion}

\subsection{Geographical disparities: the analysis of maps}

The issue of territorial disparities is a real problem in Morocco. We chose to expose it through the communal human development index (CHDI) on maps of the three scales (regions, provinces, and communes). Our first approach consists of specifying the common characteristics of developed territories and territories lagging behind in development (peripheries).

\section{Human development typology (2004/2017)}

\subsection{Typology 1: Territories with high human development (2004/2017)}

The results of the HDI in 2017 show an indicator that varies between 0.66 and 0.8 at the regional level (Fig. 2). In 2004, the $\mathrm{HDI}$ varied between 0.5 and 0.7 (Fig. 3). At the provincial level, this indicator varied between 0.59 and 0.82 in 2017 (Fig. 2). In 2004, the HDI varied between 0.2 and 0.8 (Fig. 3). In fact, at the municipal level, the variation in the CHDI in 2017 was presented by an indicator that varied between 0.26 and 0.97 (Fig. 2). The same indicator varied between 0.009 and 0.90 in 2004 (Fig. 3). As illustrated by the cartographic analysis in 2017, the most developed areas were, as expected, 

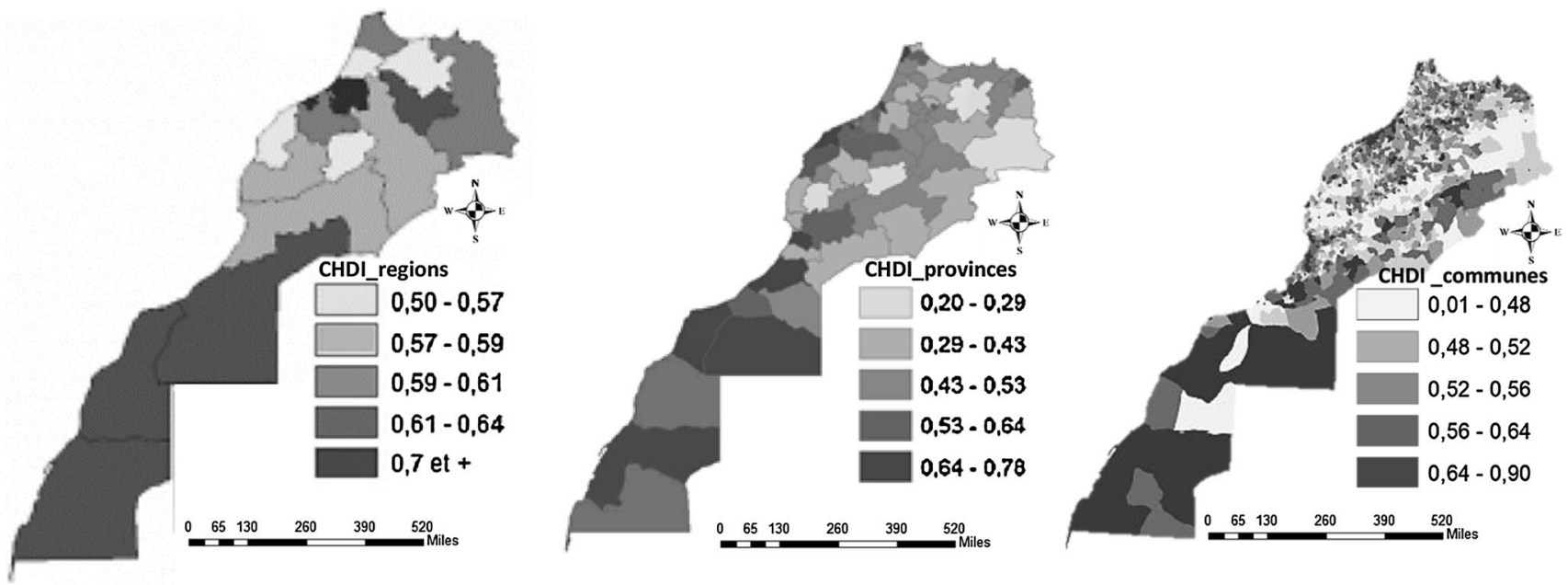

Fig. 3 Communal human development index by 16 regions, 61 provinces, 1500 communes (2004) (Source: author's, DB from [58])

the two regions of Casablanca Settat and Rabat Salé Kenitra. We also note the emergence of some regions in southern Eddakhla, Eddahab, and Laayoune Sakia Hamra. In 2004, the most-developed areas were Rabat-Salé-Zemmour-Zaër, Grand Casablanca, Laâyoune-Boujdour-Sakia el Hamra, and Oued Dahab-Lagouira. At the provincial level, in the same regions, there were two metropolises, Casablanca and Rabat. These provinces were also the most developed in 2004. The situation was similar at the communal level. In 2017, the most developed communes were located geographically in the provinces Agdal Riyad (the province Rabat) and Mechouar (the province Casablanca). In 2004, the same communes were mentioned as developed communes. These territories are historically known for their socioeconomic wealth. Economically, they are considered the most dynamic at the national level, grouping all sectors of activity (industry, services, agriculture, construction, tourism, real estate, crafts, sustainable development, fishing, etc.). As metropolitan territories, they enjoy a good quality of life due to the availability of quality socio-educational and health infrastructure.

\subsection{Typology 2: Territories with average human development (2004/2017)}

In 2017, an average level of human development characterized the Tangier-Tetouan, Oriental, Fez-Meknes, and SoussMassa regions. Likewise, in 2004, Souss-Massa-Drâa, Tanger-Tétouan, Meknès-Tafilalet, L'Oriental, Chaouia-Ouardigha, and Fès-Boulemane presented an average level of human development. The study of the common typology of regions with average human development shows a diversified character. First, the Tangier-Tetouan region is located in the north of the country. Despite considerable economic progress, this region still has social deficits, such as the education index, with a school deficit of over 48\%. Despite efforts to develop these regions (Tangier-Tetouan, Oriental, Fez-Meknes, and Souss-Massa regions) and despite efforts to develop their basic infrastructure, these regions remain at an intermediate level of human development.

\subsection{Typology 3: Territories with low human development (2004/2017)}

Low human development in Morocco is more prevalent in mountainous areas, which represent a large part of the Moroccan territory. Indeed, these isolated territories do not have access to basic services. According to the cartographic analysis, in 2017, the regions lagging behind in development were Draa Tafilalet, Beni Mellal Khénifra, and Marrakech Safi. At the provincial and communal levels, the situation was almost the same. In 2004, the regions lagging behind according to the previous administrative division were Tadla-Azilal (currently Beni Mellal Khenifra) and Marrakech-Tensift-Al Haouz (currently Marrakech Safi). In 2017, Gharb-Chrarda-Beni Hssen, Doukkala-Abda, and Taza-Al Hoceïma-Taounate were transferred according to conditions of proximity to counterbalance the following regions (Rabat-Salé-Kénitra), (Casablanca-Settat) and (Tanger-Tetouan-Al Hoceima).

The economy of these territories is structured around three spheres of wealth: agriculture, energy and mining; tourism; and the art and cultural industry. However, the difficulties inhibiting the development of this potential are inherent to 
economic and natural issues, notably the weaknesses of the reception and connectivity infrastructures and the fragility of the ecosystems of the environment of these territories.

\subsection{Human development ranking from the local to global levels}

\subsubsection{HDI ranking of Morocco}

Currently, the human development index (HDI) of Morocco barely reaches the level of many countries. At the international level, countries are distinguished in four categories according to their HDI: very high ( 0.800 or more), high (between 0.700 and 0.799 ), medium (between 0.550 and 0.699), and low (below 0.550). With an index of 0.6, Morocco is in the third category, which included 43 countries. Morocco ranks 121 st out of 187 countries in the world and is on the list of countries with medium human development [6]. In the MENA region, Morocco ranks behind all countries. Based on this finding, we will proceed to an analysis of human development performance in terms of the HDI from the local to the global level according to three scales (regions, provinces, and municipalities).

Concerning the placement of Moroccan regions according to the world ranking, the southern regions would occupy $63 \mathrm{rd}$ place, among the countries with high human development. However, the region of Beni Mellal Khenifra, if it were a country, would occupy the 117th position in the world, a difference of 54 points compared to the most developed region; it would be among the countries with medium human development in the world ranking. The analysis according to Moroccan provinces shows that the province of Rabat would occupy the 26th position in the world, among the countries with very high human development. On the other hand, the province of Taourirt would occupy the 131st position in the world, a difference of 105 points, and would be among the last of the countries with average human development. At the communal level, the international comparison shows that the commune of Agdal in the province of Rabat would take the 10th position worldwide and would be among the countries with very high human development. The commune of Oulad M'hammed, a commune in the province of Anemzi, would rank 187th, a difference of 177 points, and would occupy the last place in the world among the countries with low human development. Consequently, large gaps in human development compared to the international scale are present at the municipal level. In this regard, it should be noted that the municipality is the basic territorial level for the reduction of territorial inequalities. As a territorial unit, it plays an essential role in proximity to the population (Housing and urban planning, Education and culture, Safety, Infrastructure and transport, Health, Social welfare). Therefore, the promotion of territorial equity can play a role in reducing intraregional inequalities. The most-developed municipalities have certain characteristics that are specific to urban municipalities. For example, the urbanization rate of the communes in the province of Rabat is $100 \%$, while in Midelt Province, the urbanization rate ${ }^{3}$ is only $43.58 \%$. Within the same province of Midelt, the CHDI varies between 0.26 for the rural commune of Anemzi and 0.8 for the urban commune of Midelt. The isolation of the rural environment is also penalizing in this respect. Moreover, sociocultural constraints have an important impact on access to basic services (education and health). Thus, the average year of schooling is 1 year for some landlocked communes. According to our analysis, the most glaring territorial inequalities are observed at increasingly fine scales, as well as within the same region or even the same agglomeration.

\subsubsection{Act at the local scale against territorial disparities for a sustainable human development}

It is crucial to illuminate the importance of micro-level action to reduce the inequality of sustainable human development. Recent studies show that a local government's policy response to global issues, such as those highlighted in the SDGs, is often influenced by the need for political and economic decentralization through good governance by equipping local communities with the necessary funding to implement the SDGs [10-13]. In order to identify these challenges in the Moroccan context, we first look at the achievements and key challenges of the SDGs. From the initial implementation of the SDGs to the present day, Morocco is generally on track to achieve the SDGs, according to the African ranking. It is now ranked fourth with a score of 64.28 points. In this region, Tunisia ranks first with a score of 66.01 points, followed by Mauritius with a score of 65.95 points and Algeria with a score of 65.55 points, according to African achievement of the SDGs report (Fig. 4), Morocco is on the right track to eradicate poverty in all its forms everywhere $(G 1)$ and ensure access to sustainably managed water supply and sanitation services for all

3 The urbanization rate is the ratio of the urban population to the total population. 
Fig. 4 Moroccan average performance by SDG (Source: [59])

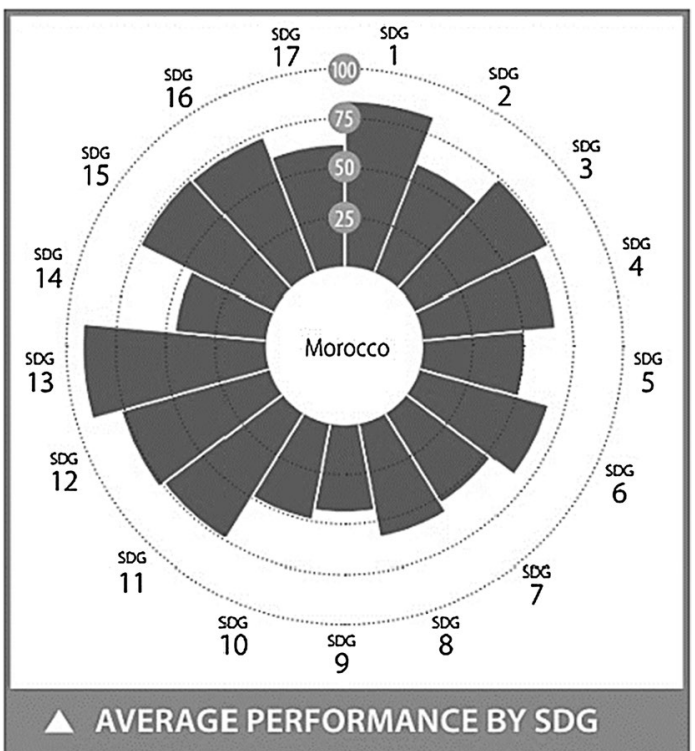

(G 6). The country also shows moderate improvement in MDGs 2, 3, 4, 5, 7, and 16 (fight against hunger, access to health, access to quality education, gender equality, renewable energy, and justice and peace). However, Morocco is faltering on 5 SDGs, namely Goals 11,13,14, 15, and 17 (sustainable cities and communities, combating climate change, conserving and sustainably using oceans and seas for sustainable development, land-based life, and partnerships for achieving the goals) [59].

Statistically, poverty has reduced to $2.9 \%$ in 2018 . In the previous years, accessibility to water in rural areas increased significantly, reaching $96 \%$ in 2016 . Other noteworthy points include the eradication of hunger, the reduction of maternal mortality to 72.6 deaths per 100,000 live births (the objective is reducing the maternal mortality for less than 70 deaths for the 2030 agenda) and infant and neonatal mortality to 22.16 and 13.56 per 1000 live births, respectively (compared to less than 25 and 12 for the 2030 agenda), the generalization of primary schooling, the achievement of gender parity in all cycles of education and the generalization of access to education for all (against less than 25 and 12 in the 2030 agenda, respectively), and the generalization of access to water and electricity. Additionally, nutrition of children under 5 years of age has improved, as wasting has been reduced to $2.6 \%$ in 2018 . Housing conditions have also improved, as the proportion of unhealthy urban housing has decreased from $8.4 \%$ in 2004 to $3.6 \%$ in 2018. In addition, significant efforts have been made in reducing rural isolation, owing to programs that build rural roads, bringing the rate of opening up in 2017 to $79.3 \%$. Similarly, the rate of medical coverage reached $68.8 \%$ in 2019 . With regard to renewable energies, Morocco is in the process of actualizing major electrical plans consisting of solar and wind sources, which has enabled it to have an electrical capacity of renewable sources representing $34 \%$ of the national capacity of the electrical mix and an electrical production of renewable origin that is $20 \%$ of the total electricity produced [35].

The common challenges to achieve the sustainable development objectives are outlined here. First, the importance of reducing territorial and gender inequalities, particularly in rural areas. Second, the acceleration of the generalization of the social protection system, particularly in favor of the poor and vulnerable populations. The challenge also lies in improving the system of governance, in particular, partnerships and clubbing of efforts of all actors. The intersection between the challenges of sustainable human development and the sets of scales (global, national, local) makes it important to specify the micro-scales for monitoring and achieving the objectives of sustainable human development. Therefore, we must question the optimal scale of territorial regulation. Based on our analysis, even in the most developed provinces, we find municipalities that lag behind in their development. The promotion of the national HDI on a global scale primarily depends on development at the grassroot level, which is likely to ensure that the poorest communities develop their capacities. 
Fig. 5 Communal human development index by regions (2004) (Source: author's, DB from [8])

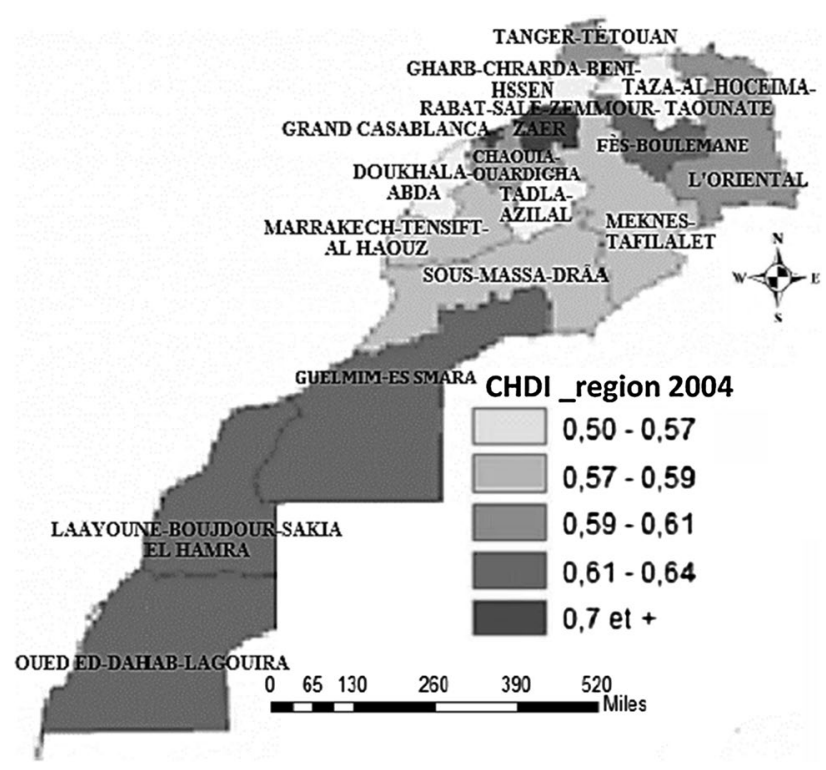

Fig. 6 Communal human development index by regions (2017) (Source: author's, DB from [58])

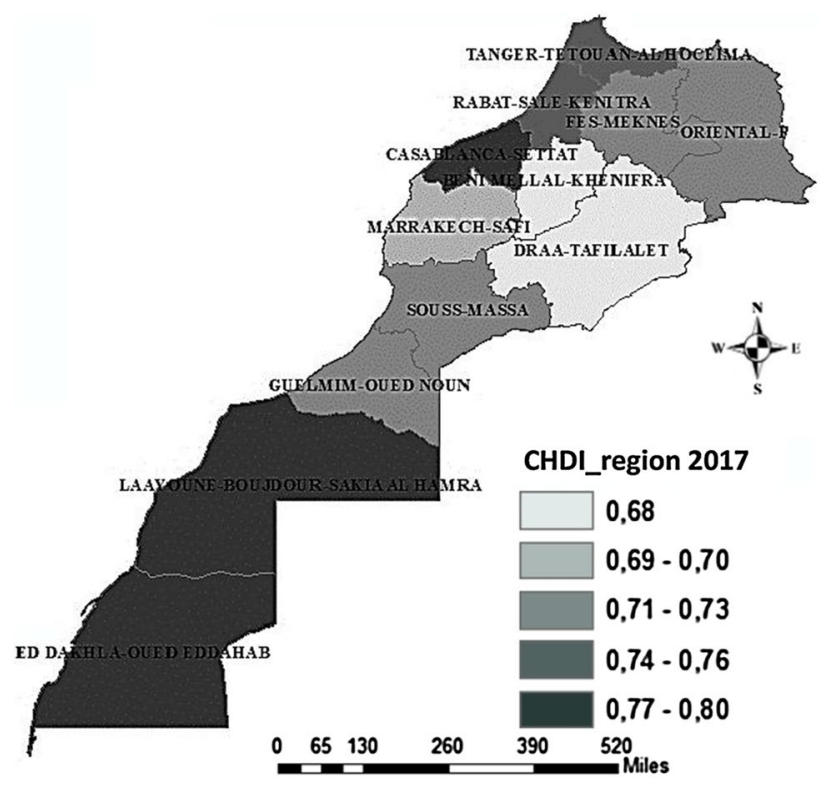

\section{The state of sub-national disparities}

The reduction in spatial disparities must be the essence of Moroccan public policies. Several programs have been announced in this context (NDHI, PRDST, etc.). Indeed, the panorama of territorial disparities in Morocco still shows certain deficits that need to be addressed. The results obtained have enabled us to highlight disparity gaps at three scales. We chose to analyze the local human development index between 2004 and 2017 to determine the effect of advanced regionalization and the new administrative division on the results of our indicators. Second, our goal is to diversify our perspectives of analysis by moving down the hierarchy from the region to the province and the commune. In this way, we compare the variability of concentration due to changes in administrative scale. The results obtained allow us to highlight the hole of disparities at the three scales.

First, it appears that the advanced regionalization project with a new administrative division of 12 regions instead of 16 (Figs. 5 and 6) and 75 provinces instead of 61 has had a significant impact on the regional disparities in Morocco. The coefficient of variation increased from 0.1 in 2004 to 0.05 in 2017 at the regional level (see Appendix: Table 3). At the provincial level, the coefficient of variation decreased from 0.28 in 2004 to 0.10 in 2017. The coefficient of variation 
remains the highest at the communal level, evolving from 0.37 in 2004 to 0.2 in 2017. From this, we deduce a notable improvement in human development levels after the new administrative division via the advanced regionalization project. In addition, following our main thesis on the possibility of improving inequalities from a local to a national level, we point out that the national HDI level went from 0.53 in 2004 to 0.67 in 2017, i.e., an improvement about 0.14 between the two study periods. Nevertheless, this improvement remains less significant at the communal level since the coefficient of variation remains the most important, with 0.2 of 2017. This figure shows the persistence of inequalities at the communal level.

\subsection{Exploratory analysis of spatial data on disparities in Morocco}

To test the sensitivity of spatial autocorrelation indices to the effects of geographic scale (MAUP), we will rely on the results of the Moran I index, which indicates the existence of spatial dependence with a positive and significant score of 0.25 in 2004 and 0.21 in 2017 at the regional scale. At the provincial level, the Moran I index increased from 0.34 in 2004 to 0.29 in 2017. At the communal scale, the score evolved from 0.44 in 2004 to 0.482017 . This result indicates that nearby places have spatially concentrated values. Therefore, spatial declination is an indicator that increases the shift from the level of regions to the lowest level of communes. This result shows the impact of scale on the spatial distribution of human development indicators. The level of spatial autocorrelation changes according to the administrative division. Thus, the level of inequality is low at the regional level (12 regions), intermediate at the provincial level ( 75 provinces), and high at the commune level (1500 communes).

Analyzing the source of communal disparities via the dimensions of the HDI in 2017, we find that the education index represents the most important spatial association score, with a significant indicator of 0.428 . The health index represents an indicator of 0.22 , and the standard of living index represents an indicator of 0.362 . This observation opens the debate on disparities in social services in Morocco. Access to education is an important determinant of territorial human development inequalities in Morocco. At the commune level, only Agdal-Riyad Hassan, Souissi (Rabat), Assoukhour Assawda and El Maarif (Casablanca), Harhoura (Skhirate-Témara), and Agdal (Fez) have an average of 9.8 to more than 12 years of schooling. On the other hand, other communes, such as Oulad Ali Mansour (Tetouan) or Tahelouante and Assais (Essaouira), do not exceed an average of 1 year. Note that the Moran I statistic is a global statistic that does not allow us to assess the local structure of the spatial autocorrelation of local indicators. Therefore, we analyzed the results of the Moran diagrams [49] and the local indicators of spatial association (LISA) [48].

According to the significance of the human development index retained in the Moran diagram in 2017, we found on the provincial map a great stability of significance overall, with the $\mathrm{HH}$ position for the economic capital (Casablanca) with 0.798 , the administrative capital (Rabat) with 0.822 , and some southern provinces (Laayoune). LL is observed for some mountainous provinces, such as Al Hoceima (0.614), Azilal (0.605), Youssoufia (0.634), Chefchaouen (0.556), Taounate $(0.57)$, and Moulay Yacoub $(0.581)$. On the other hand, the provinces with an $\mathrm{HL}$ position have recorded high human development performance, although they are surrounded by provinces with low human development, particularly Marrakech and Fez. The former has a high human development performance and is geographically concentrated in the same region. Similarly, the mountainous provinces of the Rif have low human development performance.

The mapping of local spatial autocorrelation (see Appendix: Fig. 7) reaffirms that human development remains strongly territorialized and indicates great similarity in terms of its spatial distribution. Thus, it seems that geographic location at the communal level is a discriminating factor in human development, since it conditions access to capabilities that remain inequitably distributed in Morocco. The dynamics of Morocco's communes vary greatly according to their geographic location and size. For rural communes, which are located in difficult geographical conditions, the supply of public services is generally characterized by a lack of supervision of rural activities. Basic structures cannot be made available to all settlements, as the density of populations and the dispersion of dwellings do not allow this. As one moves away from urban centers towards deep rural areas, the intervention of public authorities is insufficient. Interventions are not carried out in a coherent and equitable manner in the different territories of the country, nor are they accompanied by a significant mobilization of the private sector [60,61]. However, this lack of proximity can be mitigated by means of links to help people stay in their places of origin. In our case, spatial equity is recommended for municipalities with a very high gap in human development. The objective is to reduce extreme inequalities on the small communal scale and limit the effects of concentrated wealth and human development. 
Table 2 Distribution of NHDI expenditures by project category (in billion $\mathrm{DH}$ ) (Source: [62])

\begin{tabular}{|c|c|c|c|c|}
\hline \multirow[t]{2}{*}{ Project category } & \multicolumn{2}{|l|}{ Urban } & \multicolumn{2}{|l|}{ Rural } \\
\hline & Dotation NHDI & $\begin{array}{l}\text { Number of } \\
\text { projects }\end{array}$ & Dotation NHDI & $\begin{array}{l}\text { Number of } \\
\text { projects }\end{array}$ \\
\hline Social & 6.26 & 12183 & 2.86 & 9294 \\
\hline Economic & 0.87 & 3175 & 1.08 & 6049 \\
\hline $\begin{array}{l}\text { Equipment's basic social } \\
\text { facilities }\end{array}$ & 1.62 & 2508 & 2.93 & 8175 \\
\hline Other & 0.42 & 2113 & 0.11 & 951 \\
\hline Total & 9.17 & 19979 & 6.98 & 24469 \\
\hline
\end{tabular}

\section{Discussion}

While the aim for change towards a small scale of public action has been verified in the analysis, the importance of redefining targeting policies in Morocco must be highlighted. The objective is to better identify the needs of localities based on human development indicators. Many resources for social programs are still allocated to large cities to ensure spatial equity. The resources allocated to lagging territories also depend on the level of human development indicators at the local level in the sense that the lagging territories should receive more attention. Moreover, the deficit in the results of inequalities in Morocco at the communal level is fueled by a lack of coordination between the various actors at the local level. In this context, we question the role of territorial governance. Since communes are a permanent component of development and social actors are their central engine, it is important that territorial human development emphasize the potential of communes and the motivations of their actors.

The NHDI allowed a financial mobilization of 28.5 billion DH for the period from 2005 to 2014. The NHDI's own share amounted to 16.9 billion $\mathrm{DH}$, and the contribution of other partners reached 11.6 billion $\mathrm{DH}$, an apparent leverage of 40.7\%. During its second phase, the NHDI mobilized its own financing of approximately 2 billion DH per year. If we compare this to the National Rural Roads Program (PNRR II), which amounts to 1.55 billion DH per year, or the irrigation program endowed with 5 billion $\mathrm{DH}$ per year, the allocation of the NHDI remains relatively modest compared to its ambitions and the mobilization of 14.3 billion DH the first phase, including 8.6 billion DH contributed by the NHDI itself. In the second phase, 14.2 billion $\mathrm{DH}$ was mobilized at the end of 2014 , including 8.3 billion DH under the $\mathrm{NHDI}$, an apparent leverage of $41.4 \%$.

The analysis of the spatial distribution of committed projects shows that $53.3 \%$ of projects concern the rural environment and $43.6 \%$ concern the urban environment, the rest being intercommunal projects. This distribution is reversed when considering the project financing: 54.4\% of NHRI credits are allocated to urban areas, against $41.4 \%$ for rural areas. The gap is even greater in regard to overall funding, as urban projects benefit from greater material supplements provided by other partners. Projects in rural areas are, on average, 1.6 times smaller than those in urban areas. The average amount per project is $\mathrm{DH} 285,000$ in rural areas compared to $\mathrm{DH} 459,000$ in urban areas.

In the program to fight against exclusion in urban area, the resources of the NHDI were allocated primarily to the metropolises in the first phase. The amounts invested exceeded 20 million DH for Tangier, Rabat, Marrakech, Fez and Meknes and 62 million DH for Casablanca. The NHDI also invested remarkably in the southern provinces. The annual expenditure per capita exceeded $50 \mathrm{DH}$ in these provinces, with the exceptions of Laayoune and Tarfaya. The other provinces have benefited from per capita allocations of less than $50 \mathrm{DH}$. As an indication, the per capita allocations in the provinces of Zagora, Ouarzazate, Jerada, Fquih Ben Saleh and El-Hajeb did not exceed 15 DH even though they suffer from significant poverty and a low level of social development (Table 2). During the second phase of the NHDI, improvements towards greater equity were made in the distribution of the NHDI per capita. However, these improvements did not benefit the provinces of Chtouka Ait Baha, Al Haouz, Sefrou or Taounate, with per capita allocations of less than 15 $\mathrm{DH}$, despite their deficit in terms of social development. Efforts remain to be made to distribute NHDI expenditures more equitably. The credits granted to Casablanca dropped by $17.7 \%$ to 53 million DH [62].

The success of scaling-up policies requires a financial commitment based on spatial equity. We give the example of the European leader project. This project promotes the rural approach, which considers that progress in rural areas, such as the mountains and the Extremadura peneplain, needs a strong and dynamic economic system to support it. In summary, does the EAFRD truly fight to achieve sustainable rural development in Extremadura? Theoretically yes, but in practice, according to the results, despite its local implementation based on the proposals and postulates of neoendogenous territorial 
development, its implementation has generated spatial inequalities depending on the pre-existing socioeconomic situation. This means that the most dynamic territories are those that receive the most investments, while the rural territories, in particular the most remote and mountainous territories, are penalized. The findings of this study support the more careful evaluation of the possibility of incorporating spatial planning considerations in the context of the cohesion policy. The increasing emphasis on the place character of the policy, which is the philosophical approach that supported its reform in 2013 [63-66], requires a better focus on the actual characteristics of each territory. From this perspective, a territorial approach to economic development must be highly context-dependent, and this requires tailored interventions for spatial entities, such as remote or congested rural areas and degraded urban neighborhoods, characterized by strengths and weaknesses.

In this context, spatial equity remains an indispensable condition for the success of scaling-up policies in Morocco and achievement of the human dimension of the SDGs. In order to realize the contribution of advanced regionalization, policies should focus on providing the necessary funding to municipalities with the greatest need, using the spatial equity approach.

\section{Conclusion}

Over the past 10 years, Morocco has embarked on a process of advanced regionalization. The process of the change of scale was strengthened in the context of the implementation and monitoring of the SDGs by allowing the establishment of local centers of expertise to disseminate the concepts and practices of sustainable human development on its territories. To analyze the conditions necessary for the successful implementation of this project for a convergence of human development indicators, the objective of this study was to present an in-depth analysis of human development inequalities in Morocco. The contribution of this article is twofold, as we have highlighted the gap to be filled over a period $(2004,2017)$ through a cartographic analysis of human development indicators at three scales (the region, province and commune). We have thus identified, by means of a human development typology, the areas where human development is lagging behind, which are explicitly visible at the communal level. According to the components of the $\mathrm{CHDI}$, we have highlighted the educational component as the most disabling aspect of human development performance, especially in remote rural areas. Then, according to our empirical contribution, the analysis of global and local associations shows that the further one moves geographically away from metropolitan areas, the lower the level of human development is. This finding is verified at the municipal level. After the implementation of the new administrative division, the human development indicators improved significantly at the regional level. However, inequalities persist at the communal level. In this context, although it is almost impossible to overcome certain constraints imposed by physical geography and to correct the dysfunctions inherited from the past in a short time, it is still possible to reform our mode of targeting and governance by proceeding to a true territorialization of the state's actions.

The common goal of human development and the SDGs is to reduce inequalities that remain concentrated in the micro scales in Morocco. Accordingly, reducing territorial disparities for sustainable human development requires effective territorial governance and participatory democracy through the interaction cooperation among territorial community actors, including the public sector, the private sector, and civil society. In this sense, we emphasize the importance of having a global vision of the political context (communal dynamics, local finances, NHDI bodies, communal planning). The action of public authorities must be based on the geographical distribution of communal human development indicators. Therefore, targeting and spatial planning policies should be reviewed to address micro-level capacity gaps. Finally, future studies may follow this process in a new period of implementation of a new development project.

\footnotetext{
Authors' contributions Al: supervised and verified the analytical methods and findings. SR: wrote the main manuscript text, calculation and interpretation of results. Both authors discussed the results and contributed to the final manuscript. Both authors read and approved the final manuscript.
}

Data availability The datasets that support the findings of this study are available from the corresponding author on reasonable request.

Declarations

Competing interests The authors declare no competing interests. 
Open Access This article is licensed under a Creative Commons Attribution 4.0 International License, which permits use, sharing, adaptation, distribution and reproduction in any medium or format, as long as you give appropriate credit to the original author(s) and the source, provide a link to the Creative Commons licence, and indicate if changes were made. The images or other third party material in this article are included in the article's Creative Commons licence, unless indicated otherwise in a credit line to the material. If material is not included in the article's Creative Commons licence and your intended use is not permitted by statutory regulation or exceeds the permitted use, you will need to obtain permission directly from the copyright holder. To view a copy of this licence, visit http://creativecommons.org/licenses/by/4.0/.

\section{Appendix}

See Tables 3, 4 and Fig. 7.

Table 3 Descriptive statistics

\begin{tabular}{lrlllll}
\hline CHDI & Obs & Mean & $\begin{array}{l}\text { Standard } \\
\text { deviation }\end{array}$ & Min & Max & $\begin{array}{l}\text { Coefficient } \\
\text { of variation }\end{array}$ \\
\hline Regions 2017 & 12 & 0.74 & 0.04 & 0.66 & 0.8 & 0.054 \\
Regions 2004 & 16 & 0.60 & 0.06 & 0.5 & 0.7 & 0.10 \\
Provinces 2017 & 75 & 0.69 & 0.064 & 0.59 & 0.8 & 0.10 \\
Provinces 2004 & 61 & 0.50 & 0.14 & 0.20 & 0.8 & 0.28 \\
Communes 2017 & 1501 & 0.60 & 0.1 & 0.26 & 0.97 & 0.20 \\
Communes 2004 & 1501 & 0.40 & 0.15 & 0.009 & 0.90 & 0.37 \\
\hline
\end{tabular}

Source: Author's calculation

Table 4 Spatial autocorrelation

\begin{tabular}{llllll}
\hline CHDI & I Moran & \multicolumn{1}{l}{$\mathrm{E}(\mathrm{l})$} & $\mathrm{Sd}(\mathrm{I})$ & $\mathrm{Z}$ & P value \\
\hline Regions 2017 & 0.21 & 0.091 & 0.177 & 2.009 & 0.022 \\
Regions 2004 & 0.25 & -0.067 & 0.153 & 2.063 & 0.020 \\
Provinces 2017 & 0.29 & -0.014 & 0.074 & 3.431 & 0.000 \\
Provinces 2004 & 0.34 & -0.017 & 0.092 & 5.289 & 0.000 \\
Communes 2017 & 0.44 & -0.001 & 0.015 & 24.172 & 0.000 \\
Communes 2004 & 0.48 & -0.001 & 0.015 & 25.552 & 0.000 \\
\hline
\end{tabular}

Source: Author's calculation
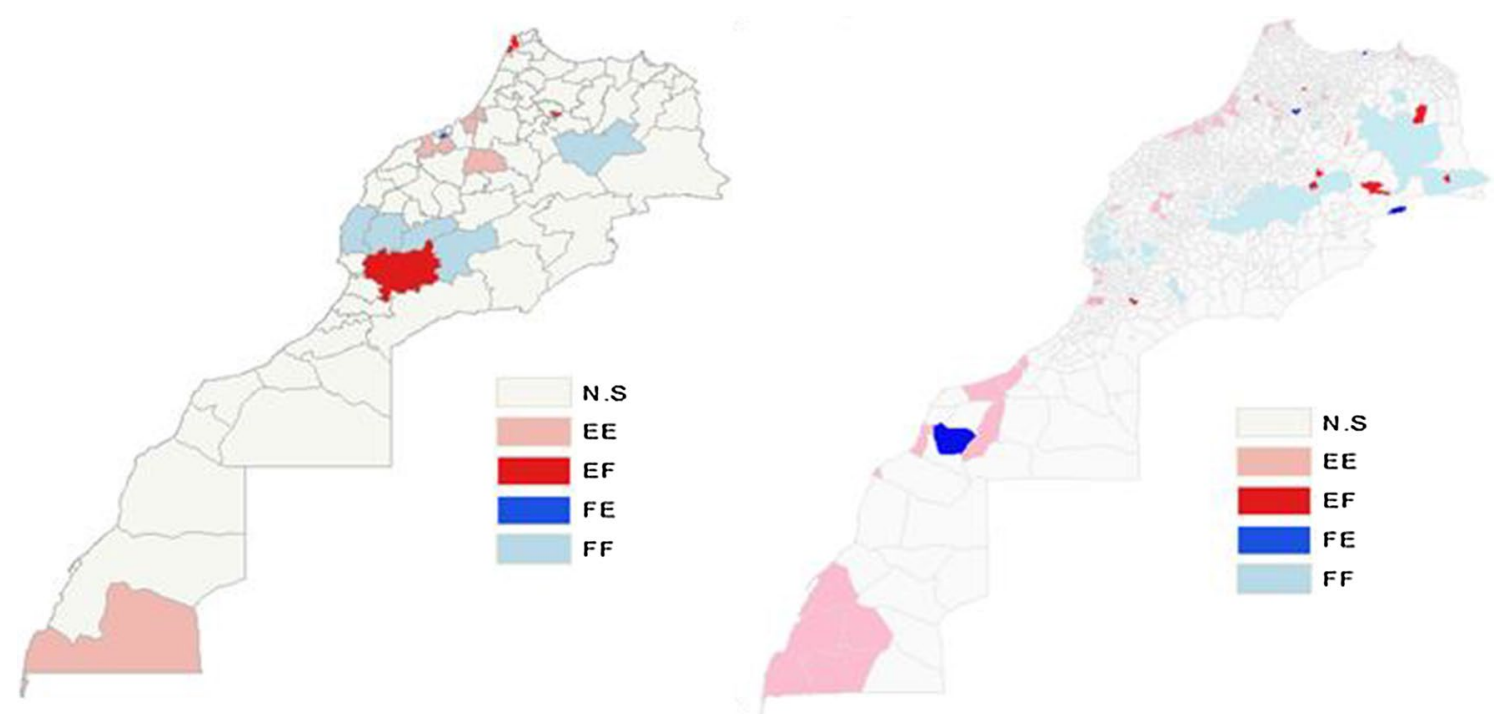

Fig. 7 Clusters and spatial outliers (Moran I) (Source: Author's calculation) 


\section{References}

1. Sen A. Un nouveau modèle économique: Développement, justice, liberté. Paris: Odile Jacob; 2010.

2. Soja EW. Seeking spatial justice. Minneapolis: University of Minnesota; 2010.

3. Bret B. La justice spatiale à l'épreuve des échelles géographiques, [Spatial Justice and Geographic Scales, traduction: Laurent Chauvet], Justice spatiale | Spatial Justice, no 12, octobre 2018. 2018. http://www.jssj.org.

4. Haut-Commissariat au Plan. Examen national volontaire de la mise en œuvre des objectifs de développement durable. 2020.

5. Commission consultative de la régionalisation Royaume du Maroc (CCR). Rapport sur la régionalisation avancée: Soumis à la Haute Attention de Sa Majesté Le Roi Mohammed VI. 2015. http://www.regionalisationavancee.ma/PageFR.aspx?id=8. Accessed 11 Mar 2019.

6. UNDP. Human development report 2019. Beyond income, beyond averages, beyond today: inequalities in human development in the 21st century. New York. 2019. http://hdr.undp.org/en/content/human-development-report-2019.

7. Adidi A. De l'aménagement du territoire au développement territorial: quelle transition et quelle articulation? 1ère Conférence Intercontinentale d'Intelligence Territoriale I.C.I. les territoires, I'Intelligence, la Communication et I'Ingénierie territoriales pour penser ensemble le développement des territoires", Gatineau 2011, Oct 2011, Gatineau, Canada. 2014. p. 11. (halshs-00960909).

8. Haut-Commissariat au Plan. Le développement socio-économique régional Niveau et disparités, 2001-2017, direction de la statistique, rabat, Maroc. 2017.

9. Aurélie Q, Marianne M. Justice spatiale, pensée critique et normativité en sciences sociales, ["Spatial Justice, Critical Thinking and Normativity in the Social Sciences", traduction: John Crisp], Justice spatiale | Spatial Justice, no 12, octobre 2018. 2018. http://www.jssj.org.

10. Rignall K, Atia M. The global rural: relational geographies of poverty and uneven development. Geogr Compass. $2017 ; 11$ (7): e12322. https://doi.org/10.1111/GEC3.12322.

11. Hughes S, Runfola DM, Cormier B. Issue proximity and policy response to local governments. Rev Policy Res. 2018;35(2):192-209. https:// doi.org/10.1111/ropr.12285.

12. Smoke P. Rethinking decentralisation: assessing challenges to a popular public sector reform. Public Adm Dev. 2015;35:97-112. https:// doi.org/10.1002/pad.1703.

13. Guha J, Chakrabarti B. Achieving the sustainable development goals (SDGs) through decentralisation and the role of local governments: a systematic review. Commonw J Local Gov. 2019. https://doi.org/10.3316/INFORMIT.896493850496702.

14. Quintal M, Trudelle C. Maroc: Les associations locales dans la vallée du Ziz. Une nouvelle gouvernance territoriale. Économie rurale. 2013;334:39-53.

15. Lévy J, Fauchille JN, Povoas A. Théorie de la Justice Spatiale. Géographies du juste et de l'injuste. 2018.

16. Planel S. Entre justice et compétitivité, le "développement territorial" au Maroc. In: Dufaux F, Philifert P, editors. Justice spatiale et politiques territoriales. Nanterre: Presses Universitaires de Paris ouest; 2013. p. 153-69. ISBN 978-2-84016-164-6.

17. El Aoufi N, Hanchane S. Les inégalités réelles au Maroc. Economie critique. 2016.

18. Polton D. Décentralisation des systèmes de santé: un éclairage international. Revue française des affaires sociales. 2004. https://doi.org/ 10.3917/rfas.044.0267.

19. Haut-Commissariat au Plan. Le marché du travail au Maroc: défis et opportunités, direction de la statistique, rabat, Maroc. 2017.

20. Benjilali M. Décentralisation du système éducatif et enjeux de la qualification des services d'enseignement et de formation. 2019.

21. Benaabdelaali W. L'effet des inégalités d'éducation sur le développement économique: un essai d'évaluation. Economies et finances. Thèse en sciences économiques. Université de Toulon. 2017.

22. Faguet J-P, Pöschl C. Is decentralization good for development? Perspectives from academics and policy makers. Oxford: Oxford University Press; 2015. p. 1-28.

23. Faguet J-P, Sánchez F. Decentralization and access to social services in Colombia. Public Choice. 2013;160(1-2):227-49.

24. Manor J. The political economy of democratic decentralization. Washington, DC: World Bank; 1999.

25. Demmelhuber T, Sturm R, Vollmann E. Decentralization in the Arab world: conceptualizing the role of neopatrimonial networks. Mediterranean Politics. 2020;2(4):499-521.

26. Harb M, Atallah S. Decentralization in the Arab world must be strengthened to provide better services, LCPS Policy Brief No. 11. 2014. http://www.lcps-lebanon.org/publications/1401092788-policybrief11lcps.pdf. Accessed 14 June 2019.

27. Kherigi I. Devolving power after the Arab Spring: decentralization as a solution. Al Sharq Forum Paper Series, 30 March, Al Sharq Strategic Research. 2017.

28. Dickovick JT, Beatty RiedI R. African decentralization in comparative perspective. In: Dickovick JT, Wunsch JS, editors. Decentralization in Africa: the paradox of state strength. Lynne Rienner: Boulder; 2014. p. 249-76.

29. Bergh SI. Public sector governance reforms and "advanced regionalization" in Morocco: what role for the European Union? EUI/RSCAS Working Paper No. 2016/56. 2016. http://cadmus.eui.eu/handle/1814/43984. Accessed 11 Mar 2019.

30. CERED. Politiques de population et développement humain au Maroc: bilan des cinquante années passées, Rabat. 2006.

31. El Jihad MD. L'eau de la montagne et le pouvoir étatique au Maroc: Entre le passé et le présent. Annales de Géographie. 2001;633:665-72.

32. Royaume du Maroc, Ministère de l'aménagement du territoire, de l'eau et de l'environnement, département de l'aménagement du territoire: Le Schéma national d'aménagement du territoire; 2001.

33. Naciri M. Territoire: contrôler ou développer, le dilemme du pouvoir depuis un siècle, monde arabe Maghreb mâcher, $\mathrm{n}^{\circ} 164$, avril-juin. 1999. p. 9-35.

34. El Bouzaidi A, Boudouah M. L'aménagement du territoire, facteur du développement économique et social marocain, entre l'héritage colonial et la globalisation économique. Espace géographique \& société marocaine, n. 15. 2016. p. 123-36.

35. Haut-Commissariat au Plan. La mise en œuvre des objectifs de développement durable. 2020.

36. Haut-Commissariat au Plan. Le Maroc entre Objectifs du Millénaire pour le Développement et Objectifs de Développement Durable. 2015.

37. Bergh SI. Democratic decentralization and local development: insights from Morocco's advanced regionalization process. In: Crawford G, Abdulai A-G, editors. Research handbook on democracy and development. Cheltenham: Edward Elgar; 2021. p. $482-501$. 
38. OECD. Morocco-OECD dialogue on territorial development policies: challenges and recommendations for coordinated public action (synthesis), Morocco country programme. Paris: OECD; 2018.

39. UNDP. Maroc-Rapport de développement humain 2003: Gouvernance et accélération du développement humain, juillet. 2003.

40. Haut-Commissariat au Plan. recensement général de la population et de l'habitat, direction de la statistique, rabat, Maroc. 2004.

41. Haut-Commissariat au Plan. recensement général de la population et de l'habitat, direction de la statistique, rabat, Maroc. 2014.

42. Haining RP. Spatial data analysis: theory and practice. Cambridge: Cambridge University Press; 2003. p. 452.

43. Anselin L. Thirty years of spatial econometrics. Pap Reg Sci. 2010;89:3-25. https://doi.org/10.1111/j.1435-5957.2010.00279.x.

44. Upton GJG, Fingleton B. Spatial data analysis by example. Chichester/New York: Wiley; 1985.

45. Anselin L. SpaceStat: a program for the analysis of spatial data. Santa Barbara: National Center for Geographic Information and Analysis, University of California; 1992.

46. Ertur C, Thiaw K. Croissance, capital humain et interactions spatiales: une étude économétrique. LEG - Document de travail - Economie 2005-04, LEG, Laboratoire d'Economie et de Gestion, CNRS, Université de Bourgogneanseli. 2005.

47. Amara M, Kriaa M, Montacer M. Centralité des activités dans la région urbaine de Tunis (1994-2004). Revue d'Économie Régionale et Urbaine. 2010;3:473-509.

48. Anselin L. Local indicators of spatial association-LISA. Geogr Anal. 1995;27(2):93-115.

49. Anselin L. The Moran scatterplot as an ESDA tool to assess local instability in spatial association. In: Fischer M, Scholten HJ, Unwin D, editors. spatial analytical perspectives on GIS. Londres: Taylor \& Francis; 1996. p. 111-25.

50. Brunet R, Dollfus O. Mondes nouveaux. Géographie universelle. Paris, Montpellier: Belin, GIP RECLUS; 1990. p. 551.

51. Mathian H. Piron M. Échelles géographiques et méthodes statistiques multidimensionnelles. In: Sanders I, editor. Modèles en analyse spatiale. Paris: hermes lavoisier, coll, information géographique et aménagement du territoire; 2001. p. 61-104.

52. Oliveau S. Autocorrélation spatiale: leçons du changement d'échelle. L'espace géographique. 2010;39(1):51-64. https://doi.org/10.3917/ eg.391.0051.

53. Openshaw SO, Taylor PJ. A million or so correlation coefficients: three experiments on the modifiable areal unit problem. In: Wrigley N, editor. Statistical applications in the spatial sciences. Londres: Pion; 1979. p. 127-44.

54. Openshaw S, Taylor PJ. The modifiable areal Unit problem. In: Wrigley N, Bennett R, editors. Quantitative geography: a British view. London: Routledge; 1981. p. 60-9.

55. Briant A, Combes PP, Lafourcade M. Dots to boxes: do the size and shape of spatial units Jeopardize economic geography estimations? J Urban Econ. 2010;67(3):287-302.

56. Auvray E. Localisation des activités économiques et dépendance à l'échelle géographique considérée. Economies et finances. Français: Université du Maine; 2019.

57. Openshaw S. The modifiable areal unit problem, vol. 38. Norwich: Geobooks; 1984. p. 41.

58. Haut-Commissariat au Plan. Pauvreté, développement humain et développement social au Maroc, données cartographiques et statistiques, direction de la statistique, rabat, Maroc. 2004.

59. SDG Center for Africa and Sustainable Development Solutions Network. Africa SDG index and dashboards report 2019. Kigali and New York: SDG Center for Africa and Sustainable Development Solutions Network; 2019.

60. Conseil économique et sociale (CESE). Rapport annuel. 2018. https://www.cese.ma/media/2020/10/Rapport-Annuel-2018-1.pdf.

61. Royaume du Maroc. Ministère de I'Aménagement du Territoire National, de I'Urbanisme, de l'Habitat et de la Politique de la Ville, RAPPORT «DYNAMIQUES ET DISPARITES TERRITORIALES», Une analyse des dynamiques spatio-temporelles du développement au Maroc (1999-2014). 2018.

62. Observatoire national du développement humain. L'initiative national de développement humain (2004_2014) acquis et enseignements. 2014.

63. Barca F, McCann P, Rodriguez Pose A. The case for regional development intervention: place-based versus place neutral approaches. J Reg Sci. 2012;52(1):134-52. https://doi.org/10.1111/j.1467-9787.2011.00756.x.

64. Organisation for Economic Co-operation and Development (OECD). Regions at a glance. Paris: OECD; 2009.

65. Organisation for Economic Co-operation and Development (OECD). How regions grow. Paris: OECD; 2009.

66. Organisation for Economic Co-operation and Development (OECD). Regions and innovation policy. Paris: OECD; 2011.

Publisher's Note Springer Nature remains neutral with regard to jurisdictional claims in published maps and institutional affiliations. 